\title{
PERAN GURU BIMBINGAN DAN KONSELING DALAM PENGEMBANGAN MINAT DAN BAKAT SISWA DI SMPN 2 SENDAWAR
}

\author{
Vincensia Herta Arbi Herrin \\ SMP Negeri 2 Sendawar
}

\begin{abstract}
ABSTRAK
Penelitian ini bertujuan untuk mengetahui peran guru bimbingan dan konseling dalam mengembangkan bakat dan minat siswa di SMPN 2 Sendawar. Metode yang digunakan adalah metode penelitian kualitatif deskriptif. Instrumen yang digunakan adalah metode wawancara, observasi dan dokumentasi. Analisis data dilakukan melalui editing, koding, klasifikasi dan penarikan kesimpulan. Hasil penelitian ini menunjukkan bahwa, guru bimbingan dan konseling berperan dalam mengembangkan minat dan bakat siswa SMPN 2 Sendawar melalui layanan kelas besar, layanan pemilihan ekstrakulikuler dan pemberiann angket peminatan.
\end{abstract}

Kata Kunci: bimbingan konseling, minat, bakat, Sendawar

\section{PENDAHULUAN}

Pendidikan merupakan jalan paling efektif dalam upaya pengembangan kemampuan manusia, melalui pendidikan peserta didik diarahkan dan dibina untuk menjadi insan yang berkarakter dan berkualitas. Guru Bimbingan dan Konseling merupakan yang ikut berpartisipasi dalam mengembangkan pendidikan di sekolah. Guru bimbingan dan konseling memiliki tanggung jawab dalam pemberian bantuan kepada peserta didik terutama dalam hal menumbuhkan kepercayaan diri agar peserta didik dapat mengembangkan potensi serta minat dan bakatnya.

Menurut Hurlock (1995), minat seseorang terhadap sesuatu akan lebih terlihat apabila yang bersangkutan mempunyai rasa senang terhadap objek tersebut. Sejalan dengan pendapat tersebut, minat adalah suatu perangkat mental yag terdiri dari suatu campuran dari perasaan, harapan, pendirian, prasangka, rasa takut, atau kecendrungan-kecendrungan lain yang mengarahkan individu kepada suatu pilihan tertentu (Mappiare, 1995). Menurut Prayitno (2009), bakat adalah milik istimewa seseorang, istimewa karena tidak semua orang memilikinya, istimewa karena hal itu merupakan hadiah atau anugrah dari Tuhan. Senada dengan hal tersebut, Muhammad (2010) menyatakan bahwa bakat adalah suatu potensi pada diri seseorang yang perlu dilatih dan dikembangkan. Dengan mengetahui minat dan bakat, maka seorang siswa akan dapat mengembangkan potensi yang ada didalam dirinya yang tentunya dapat menunjang karir dan masa depannya.

Oleh karena itu dengan memahami minat dan bakat akan membantu siswa dalam menentukan cita-cita dan masa depan serta mengetahui secara pasti sekolah lanjutan setelah menyelesaikan pendidikan di SMP. Kenyataanya disekolah masih banyak siswa yang belum memahami dan mengetahui mengenai bakat dan minat. Hal ini tentu berdampak pada gagalnya cita-cita atau masa depan siswa tersebut. Oleh karena itu, peran guru bimbingan dan konseling sangat diperlukan dalam membantu siswa untuk lebih memahami bakat dan minatnya.

Guru bimbingan dan konseling diharapkan mampu berperan penting dalam pengembangan minat dan bakat siswa. Salah satu tanggung jawab guru bimbingan dan konseling adalah membantu siswa agar 
Jurnal Inovasi BK,Volume 1, Nomor 2 Desember 2019 dapat mengembangkan potensi yang dimilikinya secara maksmal. Dengan adanya guru bimbingan dan kosneling di sekolah, diharapkan dapat membantu siswa untuk mengaktualisasikan diri dan mampu mengembangkan minat dan bakat secara optimal untuk menunjang masa depan yang baik.

Berdasarkan penelitian terdahulu yang dilakukan oleh Falah (2015) yang berjudul "Peran Guru Bimbingan dan Konseling Dalam Mengembangkan Minat dan Bakat Program Pilihan Studi Keterampilan Peserta Didik MAN 1 Magelang”. Hasil penelitian menunjukkan bahwa peran guru BK dalam mengembangkan minat dan bakat program studi keterampilan peserta didik MAN 1 Magelang yaitu sebagai tester, sebagai pemberi informasi, sebagai perencana program bimbingan dan konseling, sebagai administrator bimbingan, sebagai penasihat, dan sebagai konsultan. Penelitain lain yang dilakukan oleh Murni (2010), yang berjudul "Peran Konselor Dalam Pengembangan Bakat dan Minat Siswa Di SMPN 23 Banjarmasin". Dapat dilihat dari hasil penelitian tersebut yang menunjukkan bahwa konselor berperan dalam pengembangan bakat dan minat siswa di SMPN 23 Banjarmasin seperti melakukan penggalian bakat dan minat melalui data pribadi, angket (daftar isian) pengembangan diri, problem cheklist dan observasi siswa secara langsung, melaksanakan layanan penempatan siswa pada berbagai kegiatan ekstrakulikuker.

Berdasarkan uraian diatas, maka rumusan masalah dalam penelitian ini adalah bagaimana peran guru bimbingan dan konseling dalam mengembangkan bakat dan minat siswa di SMPN 2 Sendawar. Tujuan dari penelitian ini adalah untuk melihat peran guru bimbingan dan konseling dalam pengembangan minat dan bakat siswa di SMPN 2 Sendawar.

\section{METODE}

Metode yang dilakukan dalam penelitian ini adalah kualitatif dekriptif. Instrumen utama dalam penelitian ini adalah peneliti sendiri yang di dukung dengan teknik pengumpulan data lain seperti wawancara, observasi dan dokumentasi.

\section{HASIL DAN PEMBAHASAN}

Berdasarkan data observasi dan hasil wawancara dengan kepala sekolah, diketahui bahwa pelayanan bimbingan dan konseling di SMPN 2 Sendawar belum berjalan secara optimal karena kurangnya sarana dan prasarana. Selain itu, tugas dan peran guru bimbingan dan konseling juga seringkali di anggap sebagai guru yang berhak memberikan poin dan hukuman kepada siswa. Hal ini juga yang menyebabkan siswa menjadi takut dan cenderung tidak suka dengan adanya guru bimbingan dan konseling.

Layanan bimbingan dan konseling belum tersampaikan kepada semua peserta didik dikarenakan guru bimbingan dan konseling yang tidak memiliki jam khusus untuk dapat masuk ke kelas. Guru bimbingan dan konseling memberikan layanan kelas besar yaitu dengan mengumpukan siswa kelas IX untuk diberikan layanan Karir agar dapat membantu siswa dalam memahami bakat dan minatnya. Siswa kelas IX cukup antusias dalam mengikuti kegiatan ini. Dengan adanya layanan kelas besar ini, peserta didik mampu mengembangkan bakat dan minat untuk membantu dalam pemilihan studi lanjutan setelah lulus SMP.

Selain itu, guru bimbingan dan konseling juga mengarahkan siswa untuk mengikuti kegiatan ekstrakulikuler yang sesuai dengan minat yang mereka miliki. Hal ini tentu juga dapat membantu siswa dalam lebih memahami potensi dan bakat mereka. Guru bimbingan dan konseling juga menyebarkan angket peminatan yang harus disi oleh seluruh siswa kelas IX dalam membantu memahami minat yang akan 
digunakan untuk membantu dalam menentukan sekolah lanjutan. Peran guru bimbingan dan konseling dapat membantu siswa dalam memahami diri terutama dalam pengembangan bakat dan minat siswa di SMPN 2 Sendawar.

Cara mengenali minat dan bakat siswa dapat dilakukan dengan pemberian bantuan. Siswa yang memiliki bakat pada umumnya lebih cepat menguasai bidang yang diminatinya dibanding dengan siswa yang tidak memiliki bakat dibidang tersebut. Tugas guru bimbingan dan konseling adalah memeberikan bantuan supaya siswa tersebut dapat terus mengeksplorasi bakat dan minatnya.

Cara cepat untuk mengetahui minat dan bakat siswa adalah melalui kegiatan ekstrakurikuler. Kegiatan ini dapat menjadi wadah bagi siswa untuk terus menggali potensi dan mengembangkan minat bakat yang mereka miliki. Jika guru melihat siswa tersebut memiliki potensi yang baik untuk berkembang melalui kegiatan ekstrakurikuler yang diikutinya, maka guru harus mempertimbangkan bahwa siswa tersebut mungkin saja memiliki minat dan bakat pada kegiatan tersebut.

Menjalin kerjasama dengan orangtua siswa merupakan salah satu cara untuk mengetahui minat dan bakat. Kerjasama yang dilakukan oleh guru bimbingan konseling dengan orang tua yang terjalin dengan baik, dapat mendorong mootivasi siswa untuk dapat mengikuti kegiatan di sekolah. Hal ini tentu juga sangat baik bagi siswa untuk lebih mampu memahami potensi diri serta minat dan bakatnya.

Rutin memberikan latihan merupakan salah satu cara untuk mengenali minat dan bakat siswa. Minat dan bakat yang sudah terlihat dari siswa harus diberikan pembinaan dan pelatihan rutin. Hal ini bertujuan agar minat dan bakat dari siswa tersebut dapat berkembang dengan baik.
Memberikan evaluasi juga merupakan salah satu cara yang dapat ditempuh untuk mengenali minat dan bakat siswa. Guru bimbingan dan konseling bertugas sebagai evaluator yang bertugas memberikan masukan dan dorongan kepada siswa terkait pengembangan minat dan bakatnya..

\section{KESIMPULAN}

Peran guru bimbingan dan konseling belum terlaksana secara maksimal. Guru bimbingan dan konseling seringkali dianggap tidak memiliki pekerjaan sehingga seringkali diberi tugas tambahan seperti menjadi bendahara. Berdasarkan hasil penelitian, guru bimbingan dan konseling dapat membantu mengembangkan minat dan bakat siswa melalui layanan kelas besar, layanan pemilihan ekstrakulikuler dan pemberiann angket peminatan

\section{DAFTAR PUSTAKA}

Ali, M \& Asrori, M. Psikologi Remaja. Jakarta: Sinar Grafika Offset.

Falah, N \& Wahyuni, S.A. 2015. Peran Guru Bimbingan dan Konseling dalam Mengembangkan Minat dan Bakat Program Pilihan Studi Keterampilan Peserta Didik MAN 1 Magelang. Jurnal Hisbah Vol.12 No. 2.

Murni. M. 2010. Peran Konselor dalam Pengembangan Bakat dan Minat Siswa di SMPN 23 Banjarmasin. Skripsi. UIN Antasari Banjarmasin.

Hurlock, B.E. 1995. Psikologi Perkembangan. Jakarta: Erlangga.

Mappiare, A. 1995. Psikologi Remaja. Surabaya: Putra Al Ma"arif.

Prayitno. 2009. Dasar Teori dan Praktis Pendidikan. Jakarta: Grasindo. 